\title{
BORON MOBILITY IN EUCALYPTUS CLONES ${ }^{(1)}$
}

\author{
Jackson Freitas Brilhante de São José(2), Ivo Ribeiro da Silva ${ }^{(2)}$, \\ Nairam Felix de Barros ${ }^{(2)(5)}$, Roberto Ferreira Novais ${ }^{(2)(5)}$, Eulene \\ Francisco Silva ${ }^{(2)}$, Thomas Jot Smyth ${ }^{(4)}$, Fernando Palha Leite ${ }^{(3)}$, \\ Flancer Novais Nunes ${ }^{(2)} \&$ Fabrício Oliveira Gebrim ${ }^{(2)}$
}

\begin{abstract}
SUMMARY
Understanding the magnitude of B mobility in eucalyptus may help to select clones that are more efficient for $B$ use and to design new practices of $B$ fertilization. This study consisted of five experiments with three eucalyptus clones $(129,57$ and 58) where the response to and mobility of $B$ were evaluated. Results indicated that clone 129 was less sensitive to $B$ deficiency than clones 68 and 57 , apparently due to its ability to translocate $B$ previously absorbed via root systems to younger tissues when B in solution became limiting. Translocation also occurred when B was applied as boric acid only once to a single mature leaf, resulting in higher $B$ concentration in roots, stems and younger leaves. The growth of B-deficient plants was also recovere by a single foliar application of B to a mature leaf. This mobility was greater, when foliar-applied B was supplied in complexed (boric acid + manitol) than in non-complexed form (boric acid alone). When the root system of clone 129 was split in two solution compartments, B supplied to one root compartment was translocated to the shoot and back to the roots in the other compartment, improving the B status and growth. Thus, it appears that B is relatively mobile in eucalyptus, especially in clone 129, and its higher mobility could be due to the presence of an organic compound such as manitol, able to complex B.
\end{abstract}

Index terms: micronutrient, forest nutrition, translocation, polyol.

\footnotetext{
(1) Recebido para publicação em março de 2008 e aprovado em outubro de 2009.

${ }^{(2)}$ Soil Science Department, Federal University of Viçosa - UFV. CEP 36571-000 Viçosa (MG), Brazil. E-mails: ivosilva@ufv.br; nfbarros@ufv.br; rfnovais@ufv.br

(3) CENIBRA-Celulose Nipo-Brasileira, Belo Oriente (MG), Brazil. E-mail: fernando.leite@cenibra.com.br

(4) Soil Science Department, North Carolina State University, Raleigh, North Carolina 27695-7619, USA.

${ }^{(5)} \mathrm{CNPq}$ - Conselho Nacional de Desenvolvimento Científico e Tecnológico fellows.
} 


\title{
RESUMO: MOBILIDADE DE BORO EM CLONES DE EUCALIPTO
}

\begin{abstract}
O entendimento da magnitude da mobilidade de B no eucalipto é importante, devido a sua utilidade para a seleção de clones mais eficiente para esse micronutriente, além da projeção de novas práticas de fertilização de B. Este estudo envolveu cinco experimentos com três clones de eucalipto (129, 57 e 68), em que foram avaliadas a resposta e a mobilidade de B. Os resultados indicaram que o clone 129 foi menos sensivel à deficiência de $B$ do que os clones 68 e 57, aparentemente, em razão da sua maior habilidade de translocar $B$, previamente absorvido via sistema radicular, para tecidos jovens quando este miucronutriente tornou-se limitante na solução. O B aplicado de maneira localizada e numa única vez em uma folha madura foi retranslocado para os demais componentes das plantas (raizes, hastes e folhas novas), indicando que a aplicação foliar pode ser usada para recuperar rapidamente o crescimento de plantas deficientes. Essa mobilidade foi maior quando o B aplicado via foliar foi fornecido complexado com manitol, em vez de sozinho. Quando o sistema radicular do clone 129 foi dividido em dois compartimentos em solução nutritiva, o B fornecido a um compartimento da raiz foi translocado às raizes no outro compartimento, aumentando o teor deste micronutriente e o crescimento. Assim, as evidências indicam que o B é relativamente móvel no eucalipto, especialmente no clone 129; essa maior mobilidade poderia ser devida à presença de um composto orgânico, como o manitol, que complexaria o B para sua translocação.
\end{abstract}

Termos de indexação: micronutriente, nutrição florestal, translocação, polyol.

\section{INTRODUCTION}

Boron deficiency is estimated to occur worldwide in approximately 13.3 to 18 million ha of cultivated soils (Shorrocks, 1997). In Brazil, B-deficient soils are commonly found in the 'Cerrados' region (Goedert, 1985), where eucalyptus cultivation has expanded in recent years on the highly weathered, low fertility soils. In the absence of applied B, deficiencies in eucalyptus in this region have been characterized by dieback of apical meristems and trunk deformations (Barros et al., 1990; Gonçalves et al., 1997). In fact, $\mathrm{B}$ is one of the most limiting nutrients to eucalyptus seedling growth (Sgarbi et al., 1999).

The meristem dieback induced by B deficiency depends on the eucalyptus species (Althoff \& Oliveira, 1990). A better efficiency in B nutrition for a given species may be due to one or more mechanisms, such as: (1) ability to acquire B from the soil or growth medium; (2) the pattern of internal redistribution after $\mathrm{B}$ uptake; and (3) distinct B utilization efficiency (Rerkasem \& Jamjod, 1997). Differences in B nutritional efficiency have been frequently reported among species and genotypes of the same species (Bellaloui \& Brown, 1998; Subedi et al., 1999; Stangoulis et al., 2000, 2001). A lower B requirement of Eucalyptus camaldulensis in comparison to $E$. globulus was related to its higher efficiency in B utilization for biomass production, since $E$. camaldulensis was, in fact, less efficient in B absorption from the nutrient solution than $E$. globulus (Andrade et al., 1994). Based on the data reported by Marcar et al. (1999), the B utilization efficiency of $E$. camaldulensis was higher than of $E$. globulus.

Boron has historically been considered a nutrient with low phloem mobility (Oertli \& Richardson, 1971; Epstein, 1972; Raven 1980). Consistent with this idea is the observation that $\mathrm{B}$ deficiency in plants leads to the development of symptoms that appear initially in rapidly growing tissues. Deficiency symptoms are noticed in the root apex within hours and within minutes in the pollen tube (Gupta, 1993; Dell \& Huang, 1997). Limited retranslocation of $B$ has been attributed to its low mobility in the phloem sap and its fixation in components of mature leaves ( $\mathrm{Hu} \&$ Brown, 1994; Shelp et al., 1995). However, species and genotypes that are less sensitive to B deficiency are able to retranslocate $\mathrm{B}$ from the more mature tissues (source) to younger tissues (sink) (Shelp, 1993; Shelp et al., 1995; Brown \& Shelp, 1997; Perica et al., 2001) and this capacity of mobilizing and transporting $\mathrm{B}$ to tissues with a high demand could explain their lower sensitivity to B deficiency (Brown $\& \mathrm{Hu}, 1998)$.

Studies involving B mobility in eucalyptus in Brazil are limited, despite the amount of cultivated area (about 3 million ha) and the frequent occurrence of B deficiency. However, evidence supporting phloem mobility of B in fruit trees has been provided in experiments using the ${ }^{10} \mathrm{~B}$ isotope, where its application to mature leaves was later detected in young leaves. In experiments where ${ }^{10} \mathrm{~B}$ was applied to mature leaves of apple, pear and sweet cherry plants, up to $96 \%$ of the applied ${ }^{10} \mathrm{~B}$ was absorbed within $24 \mathrm{~h}$. About $50 \%$ of ${ }^{10} \mathrm{~B}$ absorbed by leaves was translocated within $6 \mathrm{~h}$ after application, and ${ }^{10} \mathrm{~B}$ was detected in the phloem sap of pear and apple trees as early as $2 \mathrm{~h}$ after foliar application (Picchioni et al., 1995). In olive trees, foliar-applied ${ }^{10} \mathrm{~B}$ isotope was translocated to inflorescences and fruits. Boron 
applications decreased the glucose concentration in the leaf petiole and increased manitol concentration, suggesting that a B-manitol complex could be responsible for B mobility in the phloem (Perica et al., 2001). Additional evidence for the participation of a B-sugar complex in B mobility in the phloem was provided by Brown et al. (1999), who generated transgenic tobacco (Nitociana tabacum) lines that produced sorbitol. This resulted in an increased retranslocation of $\mathrm{B}$ from older to younger tissues and enhanced the mobility of foliar-applied B. In control plants that did not produce sorbitol, B was virtually immobile. Bellaloui et al. (1999) investigated the relationship between sugar alcohol (sorbitol) content, $\mathrm{B}$ uptake and distribution, and the translocation of foliar-applied, isotopically enriched ${ }^{10} \mathrm{~B}$ in three lines of tobacco plants with different sorbitol production. Their results demonstrated that the concentration of the B-complexing sugar alcohol in the plant tissue had a significant effect on B uptake and distribution in plants, whereas the observed translocation of the foliar-applied ${ }^{10} \mathrm{~B}$ from the mature leaves to the meristematic tissues reinforces that B is mobile in sorbitol-producing plants. Nevertheless, other literature results do not support the role of polyols in phloem mobility of B. For example, Lehto et al. (2004) reported that ${ }^{10} \mathrm{~B}$ isotopes applied to mature leaves were translocated to younger leaves of several species that had a high polyol content (i.e. sorbitol in Sorbus aucuparia and Prunus padus), but a similar B mobility was also found in Ulmus gabra, which contained only small amounts of B-complexing sugars.

In the present investigation several experiments were carried out with B supply to either leaves or root system of two eucalyptus clones that differed in field responses to $\mathrm{B}$, and its distribution to plant components was determined with the following objectives: (a) evaluate the behavior of eucalyptus clones in relation to B supply; (b) evaluate the translocation of B using two distinct sources (noncomplexed - boric acid and complexed - boric acid + manitol); (c) observe the kinetics of translocation of foliar-applied B; and (d) assess the magnitude of B mobility when supplied to leaves or roots in a horizontally split-root system.

\section{MATERIAL AND METHODS}

\section{Plant material and growth conditions}

The clonal eucalyptus seedlings used in all experiments were produced by a mini-cutting technique in a substrate of $50 \%$ vermiculite and $50 \%$ charred rice shell. The three eucalyptus clones used were 129,68 and 57 . The first is a clone of $E$. grandis and the others are natural Rio Claro hybrids with unknown pollinator, whose seeds were collected from an $E$. grandis tree. These clones were selected because of their apparent differential sensitivity to B deficiency under field condition. Clone 129 was the least prone and clone 68 the most prone to meristem dieback. Clone 68 was substituted by clone 57 (also sensitive to $\mathrm{B}$ defiency) in later experiments since the production of cuttings of clone 68 in the nursery was discontinued (in view of the poor performance in dry periods under field conditions). About 20-day old seedlings were brought from the nursery to a greenhouse, removed from substrate, washed five times with deionized water and transferred to $10 \mathrm{~L}$ plastic trays filled with half strength Clark's nutrient solution (Clark, 1975) containing $0.1 \mathrm{mg} \mathrm{L}^{-1} \mathrm{~B}$. The presence of $\mathrm{B}$ in solution in this phase was essential for a good initial growth. Solutions were constantly aerated and the $\mathrm{pH}$ value was maintained at 6 by daily additions of diluted acid or base. Seedlings were kept in these trays for a 15day greenhouse acclimatization period prior to experimental use.

\section{Experiment 1. Differential sensitivity of eucalyptus clones to $\mathrm{B}$ omission}

This experiment evaluated the timing for appearance of B-deficiency symptoms and the response of two eucalyptus clones to B deficiency. Treatments consisted of a $2 \times 2$ factorial combination of two clones (129 and 68) and two B levels (absence or presence of $0.1 \mathrm{mg} \mathrm{L}^{-1} \mathrm{~B}$ ). This B level was defined based on a previous study with eucalyptus (Andrade et al., 1994). The experimental design was a completely randomized block, with three replications (two plants per replication). The seedlings of clones 129 and 68 were removed from the acclimatization solution and their root system was rinsed three times with deionized water, before transferring to $10 \mathrm{~L}$ plastic trays containing Clark's nutrient solution. The B concentration in solution was pre-adjusted according to the respective treatments. Each tray represented an experimental unit.

During the experimental period, nutrient solutions were aerated and the $\mathrm{pH}$ value was daily adjusted to 6.0. The development of visual B-deficiency symptoms was monitored and recorded. Thirty days after beginning the treatments, the seedlings were individually removed from solution and their root system thoroughly rinsed thrice with deionized water. Roots and shoots were dried under forced air at $70^{\circ} \mathrm{C}$ for $72 \mathrm{~h}$, weighed to obtain the shoot dry matter (SDM) and root dry matter (RDM) and ground on a stainless steel mill. The total dry matter (TDM) of plants was calculated as the sum of SDM and RDM. Subsamples of $0.1 \mathrm{~g}$ of ground material were ashed in porcelain crucibles at $550{ }^{\circ} \mathrm{C}$ for $3 \mathrm{~h}$. Tissue B concentration was determined colorimetrically by the AzomethineH method (Bingham, 1982).

\section{Experiment 2. Differential B retranslocation of two eucalyptus clones}

The hypothesis was tested that $\mathrm{B}$ absorbed via root systems, during a period of adequate supply, could be 
mobilized from mature to young tissues and sustain growth when the B plant availability is later limited. The reasoning was that in the absence of stable ${ }^{10} \mathrm{~B}$ and ${ }^{11} \mathrm{~B}$ isotope techniques (Hu et al., 1997; Huang et al., 2001; Lehto et al., 2004), a sustained plant growth under conditions of lower B availability (or even its total absence) in solution would be an indicator of $B$ retranslocation.

First, clones 129 and 68 were grown for 40 days in nutrient solution containing $0.1 \mathrm{mg} \mathrm{L}^{-1} \mathrm{~B}$ and then transferred to Clark's nutrient solution at different B concentrations $\left(0.1,0.05,0.01\right.$ and $\left.0 \mathrm{mg} \mathrm{L}^{-1}\right)$. The highest dose concentration was the same as that used in the previous phase. Treatments consisted of a factorial combination of two eucalyptus clones and four B concentrations in solution, in a complete randomized block design with three replications. Plants were harvested 40 days after transferring plants to the second solution treatments, using the same procedures described for experiment 1 . The B concentrations in solution required by each clone to reach $90 \%$ of maximum RDM, SDM and TDM were determined based on equations relating these plant variables to $\mathrm{B}$ concentrations in solution.

\section{Experiment 3. Translocation of foliar-applied non-complexed and complexed boron}

Most B absorbed by plants is incorporated into functional cell wall groups, resulting in low retranslocation (Blevins \& Lukaszewski, 1998). Since B forms a stable complex with the polyol manitol (Loomis \& Durst, 1992), we tested whether foliarapplied B in a complexed form with manitol would be more easily translocated to other plant tissues than when applied in non-complexed form (boric acid).

Seedlings of the clones 129 and 68 acclimatized for 15 days in the presence of $B\left(0.1 \mathrm{mg} \mathrm{L}^{-1}\right)$ were transferred to B-free nutrient solutions and grown for 30 days, using similar procedures as in experiment 1. Treatments were applied when the B-deficiency symptoms became visible. They consisted of foliar application of boric acid $\left(10 \mathrm{~g} \mathrm{~L}^{-1}\right)$ or boric acid plus manitol (molar ratio 1:1) to a B-deficient leaf. These solutions were applied by submerging one mature leaf of each plant in the respective solutions for one minute. This leaf was identified with a piece of cotton string. The remaining leaves were covered with paper towels to avoid any undesirable spillover contamination. For comparison purposes, a positive control treatment was included where plants were supplied with $\mathrm{B}\left(0.1 \mathrm{mg} \mathrm{L}^{-1}\right)$ throughout the experiment.

The treatments were arranged in a completely randomized design, with three replications. Each replication consisted of two plants. Nutrient solutions were constantly aerated and renewed weekly. Solution pH was adjusted daily to 6.0 .

Plants were harvested after 40 days and shoots were separated in stem, mature leaves and young leaves (including meristems). Leaves treated with B were not harvested. Roots were removed from solutions and rinsed three times with deionized water. All samples were oven-dried, weighed, ground and their B concentrations determined by the Azomethine-H method.

\section{Experiment 4. Kinetics of translocation of foliar-applied B}

Twenty one plants of the eucalyptus clones 129 and 57 previously acclimatized to a nutrient solution containing $0.1 \mathrm{mg} \mathrm{L}^{-1} \mathrm{~B}$ were individually transferred to plastic pots filled with $2 \mathrm{~L}$ of Clark's nutrient solution, with $0 \mathrm{mg} \mathrm{L}^{-1} \mathrm{~B}$. Thereafter, boric acid (5 $\left.\mathrm{g} \mathrm{L}^{-1}\right)$ was applied once to a mature leaf, as described for experiment 3. The B-treated leaf was identified with a cotton string.

The B-treated leaf was removed from the plant at different times $(0$ - just after application, after $0.5 ; 1$; $2 ; 4 ; 8$ and 27 days). The reasoning was that maintaining the B-treated leaf (the only B source) on the plant for distinct time periods, would allow an assessment of the timing and magnitude of foliarapplied B translocation to other plant parts. Plants of each clone and all treatments were harvested on the last date of the B source-leaf removal (27 days after starting the experiment). The harvested plants were separated into different components, dried, ground and analyzed for $\mathrm{B}$ as described for experiment 3 . Unlike in experiment 3 , the B source-leaves harvested at different times after $\mathrm{B}$ application were also analyzed for $\mathrm{B}$ concentration.

The experiment was arranged in a completely randomized design and each treatment had three replications. Experimental care and conditions were similar to those described for experiment 1.

\section{Experiment 5. Growth and translocation of boron evaluated in a split-root system}

Seedlings of clone 129 pre-conditioned in the presence of B were transferred to a double pot system that divided the roots in two compartments. Each pot (root compartment) was previously filled with $3 \mathrm{~L}$ of Clark's nutrient solution where the following four treatments were applied: 1 - B $\left(0.1 \mathrm{mg} \mathrm{L}^{-1}\right)$ supplied to both root compartments $(+\mathrm{B}+\mathrm{B}) ; 2-\mathrm{B}\left(0.1 \mathrm{mg} \mathrm{L} \mathrm{L}^{-1}\right)$ supplied only to root compartment 1 (+B-B); 3 - B supplied to neither root compartment (-B-B); and 4 B supplied to neither root compartment, but foliarapplied boric acid $\left(5 \mathrm{~g} \mathrm{~L}^{-1}\right)$ by submerging a mature leaf for one minute (-B-B, + B foliar).

Each treatment had three replications and the experimental units were arranged in a completely randomized block design. Thirty days after beginning the B treatments the seedling shoots were harvested and the root system of each compartment was removed separately. The plant material was dried, weighed, ground and B concentrations were determined by the Azomethine- $\mathrm{H}$ method. 


\section{Statistics}

Data of all experiments were submitted to analysis of variance after homogeneity of variances was confirmed. Tukey's honesty test was applied to discrete variables, whereas regression models were adjusted for quantitative treatments. All statistics were performed with the software packages SAEG 9.0 and SigmaPlot 9.0.

\section{RESULTS AND DISCUSSION}

\section{Differential sensitivity of eucalyptus clones} to B omission

Dry matter yield of root, stem and young leaves for both eucalyptus clones was significantly $(p<0.05)$ reduced when $\mathrm{B}$ was omitted from the nutrient solution (Figures 1 and 2), corroborating previous findings of Sgarbi et al. (1999) that B deficiency during early growth stages limits plant growth. In the absence of $\mathrm{B}$, the typical visual symptoms of reduced shoot and root were observed in the seedlings. The deficiency symptoms became evident 20 days after beginning the treatment without $\mathrm{B}$, when leaves turned pale yellow followed by appearance of reddish spots, border curling and tissue death. In this final stage the leaves were very brittle. These symptoms were more evident in clone 68 than in 129 . In the former, even meristem dieback was observed in later stages of deficiency, resulting in a complete growth stop (data not shown). Although clone 129 was affected
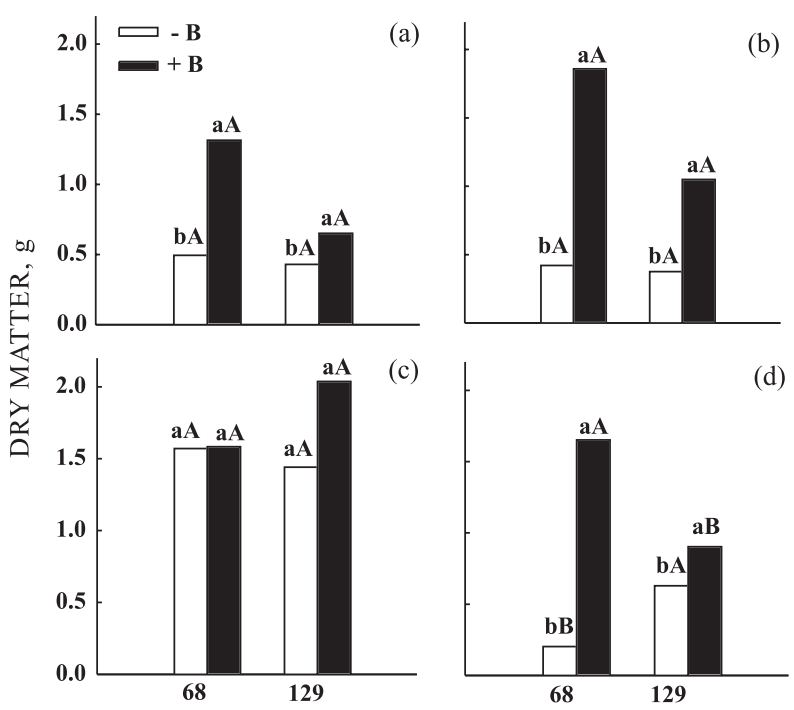

Figure 1. Dry matter mass of different plant components (a - root; b - stem; c - mature leaves; $d$-young leaves) of two eucalyptus clones (129 and 68) in absence or presence of $B$ in solution. Means followed by the same letter do not differ by Tukey's test (5\%). Small letters refer to $B$ treatments and capital letters refer to clones.

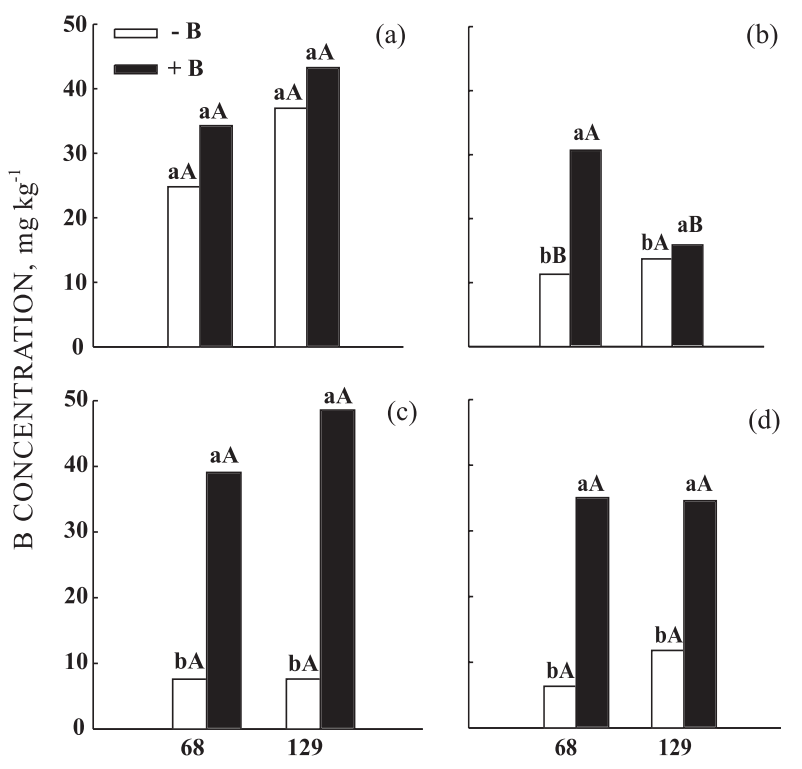

Figure 2. Boron concentration in different plant components (a - root; b - stem; c - mature leaves; $d$-young leaves) of two eucalyptus clones (129 and 68) in the absence and in the presence of $B$ in the nutrient solution. Means followed by the same letter do not differ by Tukey's test (5\%). Small letters refer to treatments and capital letters refer to clones.

by the $\mathrm{B}$ deficiency, no meristem dieback was observed while growth continued more slowly than in B supplied seedlings, as evidenced by the greater mass of young leaves and meristems in absence of B (Figure 1). Possibly, the ability of clone 129 to maintain a higher B concentration in young leaves and meristems, as reported for other plant species (Shelp, 1993; Shelp et al., 1995; Brown \& Shelp, 1997), contributed to the superior performance of clone 129.

The B root concentrations were not influenced by solution treatments and remained at similar levels in both absence and presence of B (Figure 2a). The relatively high $\mathrm{B}$ content in root tissue of treatments without $B$ is probably due to the fact that all seedlings were previously acclimatized in solutions containing B. This suggests that B absorbed during an early growth stage is difficult to be mobilized from roots. In fact, most B in plant tissue plays a structural role and is associated to cell walls (Matoh et al., 1992), apparently in a 1:2 borate:diol complex (Kobayashi et al., 1996). Under B-deficiency conditions, up to $96 \%$ of the B may be present in the cell walls (Hu \& Brown, 1994).

In the shoot components (stem, young and mature leaves) B concentrations were significantly reduced in both clones when B was omitted from solution (Figures 2b,c,d), but the difference compared to Bsupplied plants, especially in stems and young leaves, was proportionally higher to clone 68 than clone 129 . The mechanism involved in the greater tolerance of 
clone 129 to B deficiency is still unknown, but may be related to a lower pectin concentration in the cell walls (Hu et al., 1996) or the presence of higher soluble sugar concentrations that complex B and increase its mobility in the plant (Brown \& Hu, 1998).

\section{Differential B retranslocation by two eucalyptus clones}

Clone 129 was less responsive than clone 68 to decreasing $\mathrm{B}$ concentrations in solution after initial acclimatization in a solution with $0.1 \mathrm{mg} \mathrm{L}^{-1} \mathrm{~B}$. Likewise, there was no significant change in the RDM to $\mathrm{B}$ concentrations in solution, with average mass values of 12.41 and $11.08 \mathrm{~g} /$ pot for clones 129 and 68 , respectively (Figure 3a). A similar behavior was observed for the SDM of clone 129, with an average of

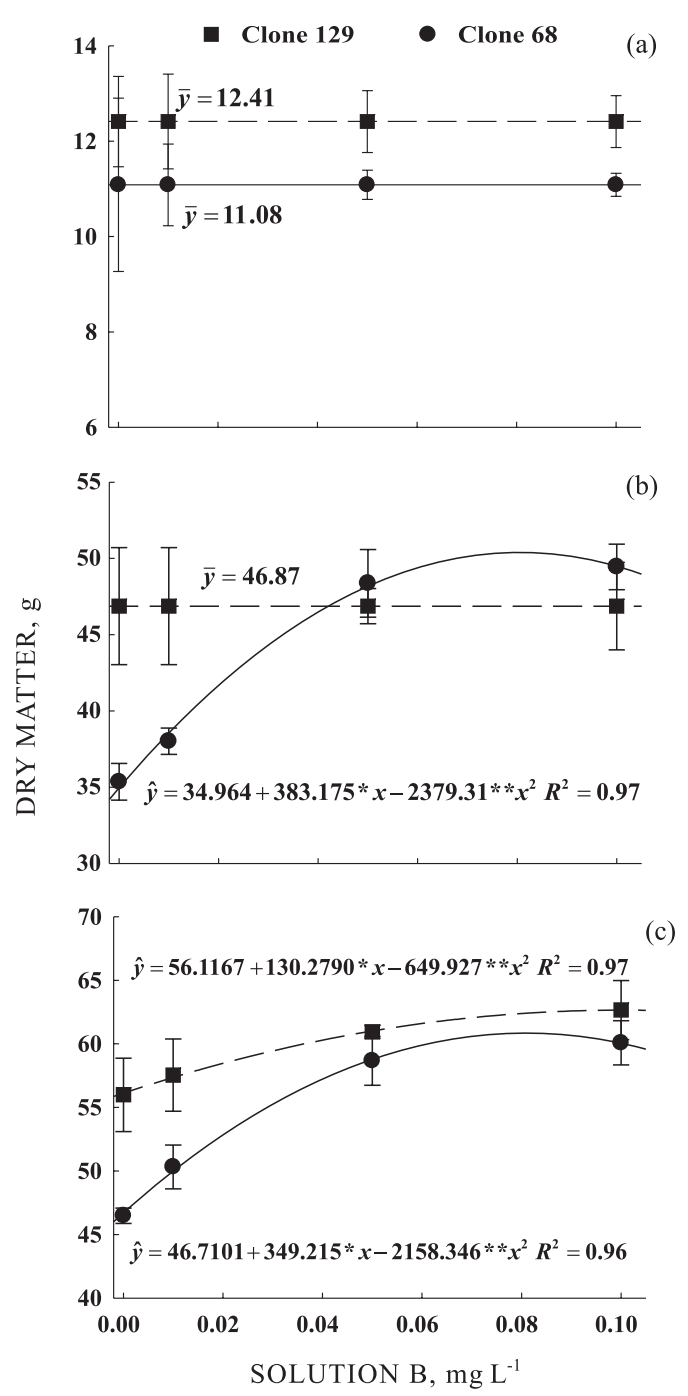

Figure 3. Dry matter of roots (a), shoots (b), and total dry matter (c) of two eucalyptus clones (129 and 68) exposed to variable $B$ concentrations in solution after an initial period of acclimatization in the presence of $B$ in the nutrient solution. Vertical bars are the standard errors.
$46.87 \mathrm{~g} / \mathrm{pot}$. There was a quadratic response to B in solution in stem dry matter of clone 68 , requiring an estimated $0.034 \mathrm{mg} \mathrm{L}^{-1} \mathrm{~B}$ in solution to reach $90 \%$ of maximum SDM (45.31 g) (Figure 3b). Ninety percent of TDM (56.38 g) for clone 129 required an estimated $0.0021 \mathrm{mg} \mathrm{L}^{-1} \mathrm{~B}$ in solution, whereas the solution B concentration $\left(0.028 \mathrm{mg} \mathrm{L}^{-1}\right)$ to achieve a similar yield level (54.76 g) with clone 68 was 10 times greater (Figure 3c). Again, these results show that clone 129 was more efficient than clone 68 in converting each unit of B into biomass, possibly through operation of mechanism(s) that allow(s) greater B mobilization from older to younger tissues, as reported for other plant species (Brown \& Shelp, 1997). This was corroborated by the fact that B concentrations in clone 129 were higher in all plant components than in clone 68. For example, in roots the maximum B concentration was $41.33 \mathrm{mg} \mathrm{kg}^{-1}$ in clone 129 and $33.97 \mathrm{mg} \mathrm{kg}^{-1}$ in clone 68 . These root $\mathrm{B}$ concentrations were achieved with solution $\mathrm{B}$ concentrations of 0.088 for the former and $0.109 \mathrm{mg} \mathrm{L}^{-1}$ for the later (Figure 4a). A similar pattern, where higher B concentration in tissue was attained with a lower B concentration in solution for clone 129 than clone 68 was also evident for the stem (Figure 4b), young leaves (Figure 4c) and mature leaves (Figure 4d). Although a dilution of tissue $\mathrm{B}$ due to continued plant growth occurred under lower $\mathrm{B}$ concentration in solution, this suggests that plants were able to use previously absorbed $\mathrm{B}$ and maintain growth during the experimental phase with limited B supply to roots. In a prior study with three eucalyptus species, the omission of $\mathrm{B}$ after a period of supply also led to reduced shoot dry matter accumulation (Marcar et al., 1999), indicating a retranslocation of $\mathrm{B}$ from mature to younger tissue.

It has been reported for some species that soluble sugar alcohols, particularly the polyols, complex B and facilitate its transport to plant tissues with greater B demand, such as young leaves and meristems (Brown \& Hu, 1998; Brown et al., 1999; Perica et al., 2001), which is a possibly a similar mechanism of adaptation as observed for eucalyptus, particularly clone 129. Although such sugars occur widespread in plants (Bieleski, 1982; Noiraud et al., 2001), this is unlikely to be the only basis for adaptation to B deficiency since some plant species that mobilize B efficiently do not have substantial amounts of such sugars, and other species that do retranslocate B do not present substantial amounts of sugars with potential to complex B (Lehto et al., 2004).

\section{Translocation of foliar-applied non-complexed and complexed boron sources}

The single application of B as boric acid to one mature leaf of B-deficient seedlings led to a substantial recovery of growth. In clone 68 , where the meristem was already dying back due to the lack of B in solution, there was new growth mainly by emission of new lateral branches below the B-treated leaf. This 
(a)
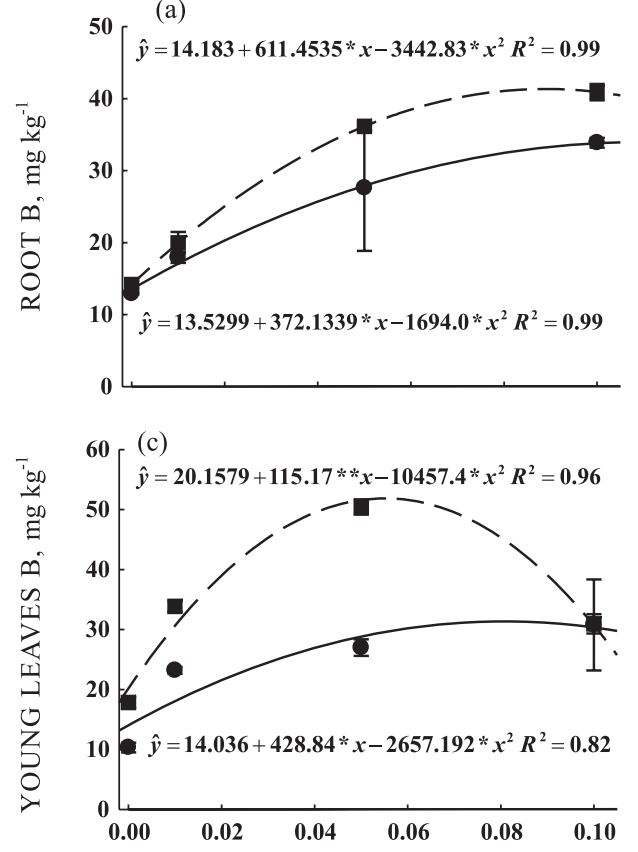

(b)
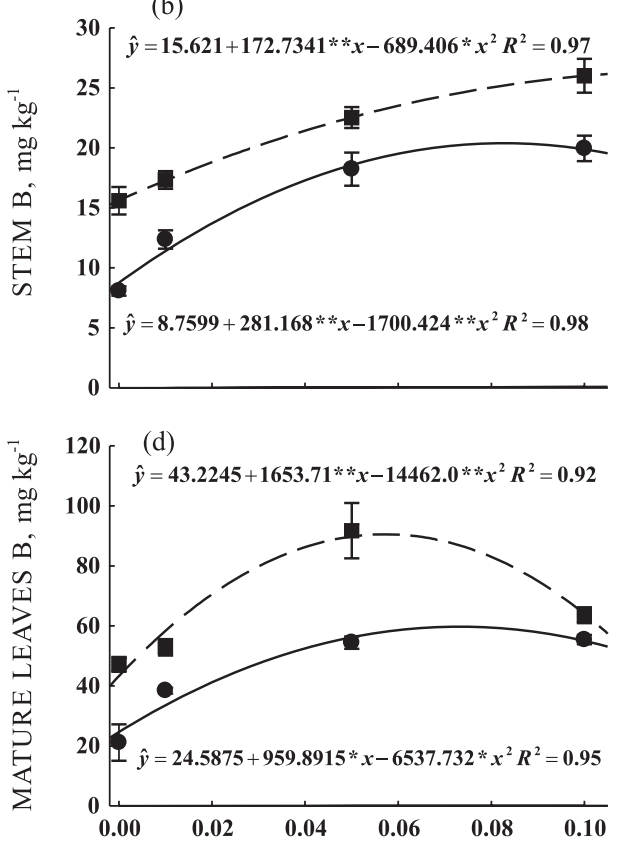

SOLUTION B, mg L ${ }^{-1}$

Figure 4. Boron concentration in roots (a), shoots (b), and total dry matter (c) of two eucalyptus clones (129 and 68) exposed to variable $B$ concentrations in solution after an initial period of acclimatization in the presence of $B$ in the nutrient solution. Vertical bars are the standard errors.

response suggests that foliar-applied B was translocated to other plant parts and new cells were stimulated to divide and elongate. In forest species there are indications that shoot-applied ${ }^{10} \mathrm{~B}$ is translocated to roots via phloem (Lehto et al., 2000).

In these experiments with eucalyptus there was, however, a differential effect between the two B sources tested (boric acid or boric acid + manitol). Dry matter accumulation in roots, stems, young and mature leaves of both clones did not differ $(p>0.05)$ between treatments receiving non-complexed B (boric acid) in comparison to the complexed form (boric acid + manitol). The complexed B source, however, clearly showed a trend to higher B concentrations in all plant tissues relative to the non-complexed boric acid, but only in the root tissue this difference was significant (Figure 6). Earlier studies showed that the organic B-manitol complex had greater mobility in plants $(\mathrm{Hu}$ et al., 1997; Brown et al., 1999). Higher B concentrations in eucalyptus tissue of plants treated with a complexed B source possibly reached toxic levels and reduced plant growth (Figure 5). According to Novais et al. (1986), the critical level for B in eucalyptus leaves is about $40 \mathrm{mg} \mathrm{kg}^{-1}$. In the treatments with complexed B, B concentrations in leaves approached $60 \mathrm{mg} \mathrm{kg}^{-1}$ and almost $100 \mathrm{mg} \mathrm{kg}^{-1}$ in roots of clone 68 (Figure 6), in which root growth was more affected when treated with boric acid + manitol (Figure 5).

The fact that even a non-complexed source of B applied to mature leaves is relatively mobile points to the existence of compounds that complex foliar-applied $\mathrm{B}$ and translocate it to other plant parts. Research has demonstrated that the sugar alcohols sorbitol and manitol may play this role in other plant species (Hu
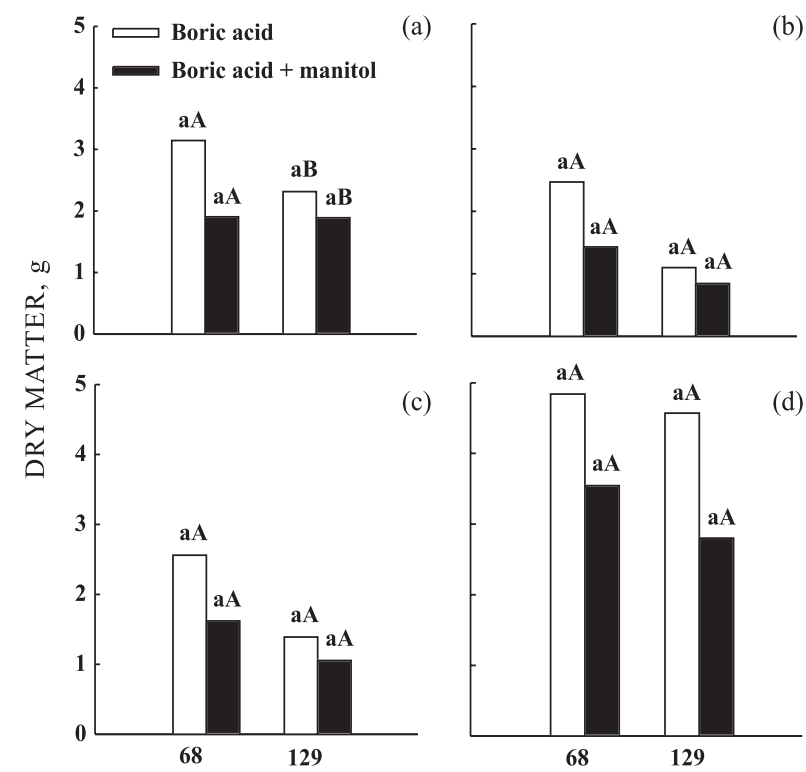

Figure 5. Dry matter of plant components (a - root; b - stem; c - mature leaves; $d$ - young leaves) of two eucalyptus clones (68 and 129$)$ in response to foliar application of boric acid or boric acid + manitol. Means followed by the same letter do not differ by Tukey's test (5 \%). Small letters refer to $\mathrm{B}$ treatments and capital letters refer to clones. 
\& Brown, 1994; Hu et al., 1997; Brown et al., 1999; Perica et al., 2001), or pinitol (Lehto et al., 2004), but the relationship between the amount of B-complexing polyols in plant tissue and its mobility is not always clear (Lehto et al., 2004).

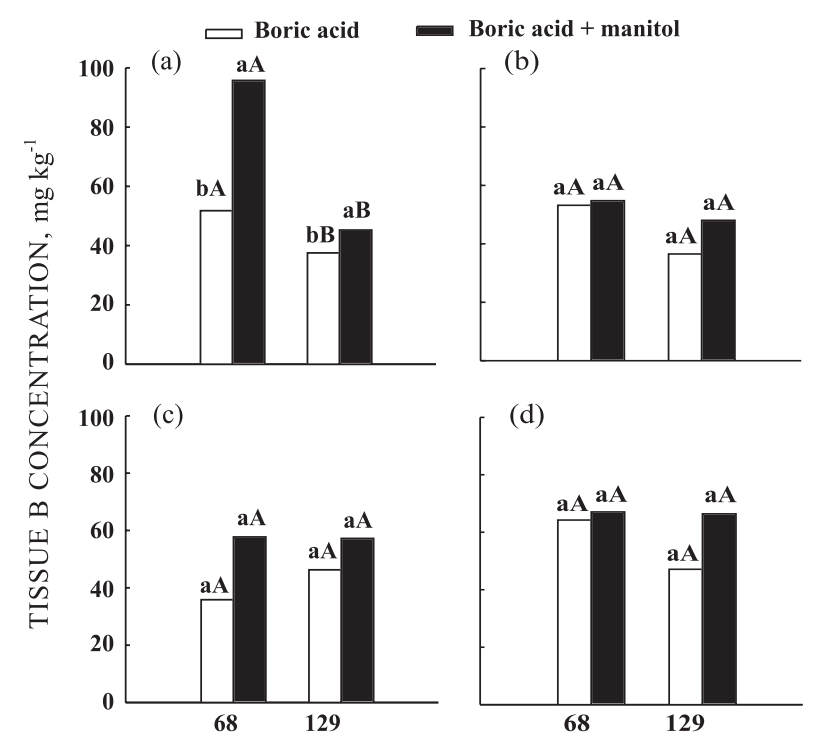

Figure 6. Boron concentration in plant components (a - root; b-stem; c-mature leaves; $d$ - young leaves) of two eucalyptus clones (68 and 129) in response to foliar application of boric acid or boric acid + manitol. Means followed by the same letter do not differ by Tukey's test (5 \%). Small letters refer to $B$ treatments and capital letters refer to clones.

\section{Kinetics of translocation of foliar-applied B}

Application of boric acid to a mature leaf of a Bdeficient plant recovered growth (Figure 7) and increased tissue $\mathrm{B}$ concentration when the B-treated (source) leaf remained attached to the plant for more than two days (Figure 8b,c,d), leading to gains in dry matter accumulation of plant components for both clones on the $27^{\text {th }}$ day with exception of new leaves (Figure 9a,b,c,d). The absence of increment in new leaf mass does not necessarily mean that there was no leaf growth response to B. It may rather be explained by the fact that the new, small leaves may have already expanded by the sampling time so that new emerged leaves were always sampled. Roots reached maximum growth when the source leaf remained attached to the plants for 18 and 20 days (Figure 9a), 20 and 18 days for the stems (Figure 9b) and 10 and 8 days for mature leaves (Figure 9c) of clones 129 and 57, respectively. The decline in B concentration of the B-treated source leaf and the gains in B concentration in other plant components, along with the growth response, indicate that absorption and transport of foliar-applied B are rapid processes (within hours), as has been demonstrated by Picchioni et al. (1995) in several fruit species.

\section{Growth and B translocation evaluated in a split-root system}

In the experiment where the root system was split into two solution compartments, SDM and RDM were reduced in the treatment without $\mathrm{B}$ addition to either compartment (-B-B). Contrastingly, plants that were supplied with $B$ via nutrient solution in both root compartmens $(+\mathrm{B}+\mathrm{B})$ produced most shoot and root dry matter (Figure 10a). In the -B-B + foliar B treatment, the response of roots indicate that foliarapplied B was mobilized and sustained a relatively good growth, leading to gains in SDM and RDM in both compartments when compared to the -B-B treatment (Figure 10a). These results show that foliarapplied B was redistributed to other plant parts, which is supported by the increase in B concentration of tissues not treated with B (Figure 10b). Additionally, it was also evident that B supply to half the root system (compartment 1) via nutrient solution (+B-B treatment) increased the $\mathrm{B}$ concentration of roots of compartment 1 , as expected, but also increased the B content in shoot as well as roots of compartment 2 , which had not been supplied with B via nutrient solution. Thus, it is clear that B absorbed by the roots in compartment $1(+\mathrm{B})$ was translocated to the shoot and retranslocated back to the roots of compartment $2(-B)$. This is another piece of evidence that supports the hypothesis that B is relatively phloem-mobile in eucalyptus. It is likely that this B transport within the plant occurrs by a yet to be determined soluble complex. The importance of complexation and B transport by sugar alcohols was demonstrated in other plant species (Brown \& Hu, 1998; Brown et al., 1999, Perica et al., 2001). Manitol is a rather ubiquitous sugar alcohol, found in more than 100 plant species (Bieleski, 1982) and has been

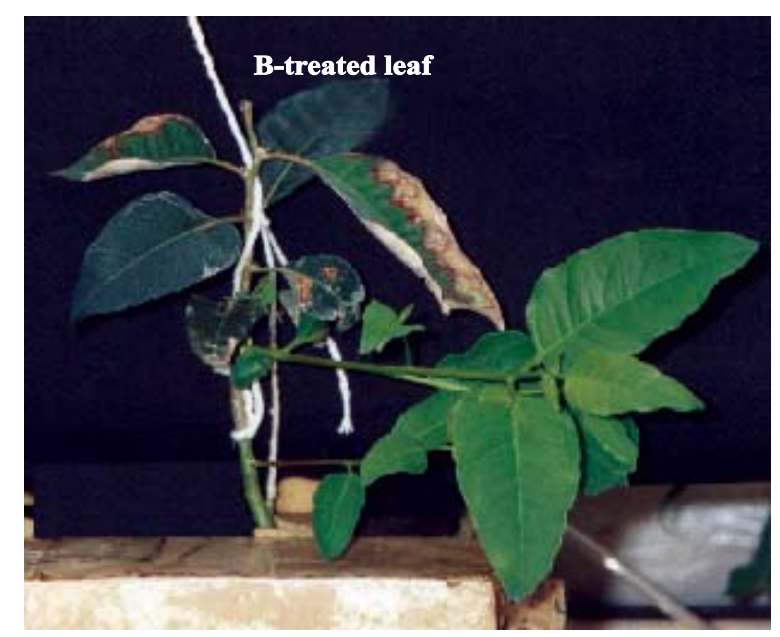

Figure 7. Visual aspect of a B-deficient eucalypt seedling (clone 129) approximately 20 days after application of a boric acid solution to a mature leaf. 
(a)

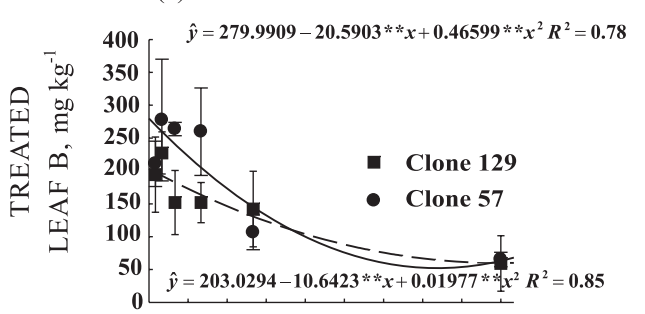

(c)

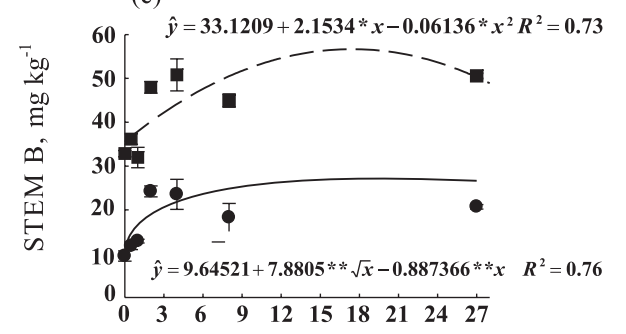

(b)

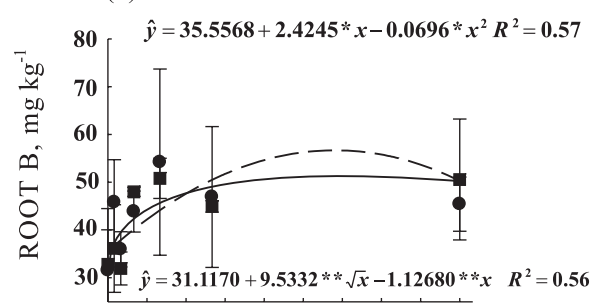

(d)

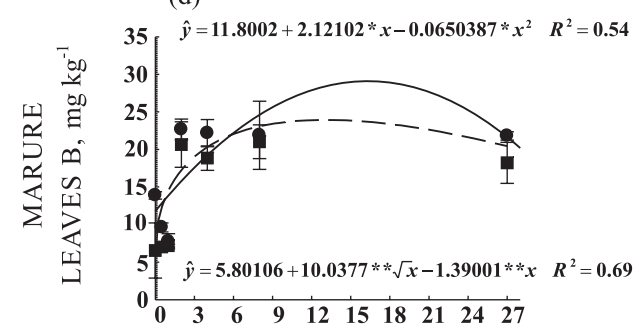

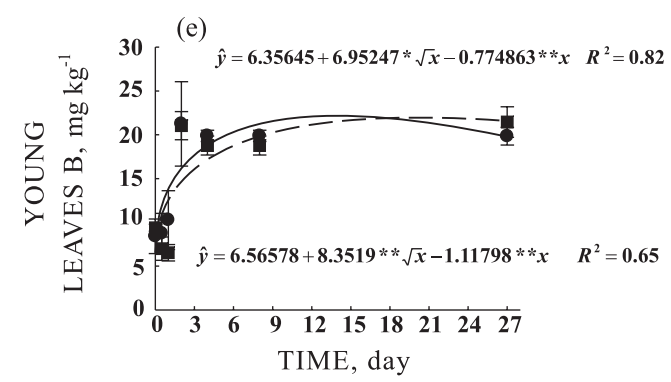

Figure 8. Boron concentration in roots (b), stem (c); mature leaves (d) and young leaves (e) of two eucalyptus clones (129 and 57) after a single application of boric acid to a mature, source leaf (B-treated) (a) as affected by the time before removal of the leaf. Plants of all treatments were harvested 27 days after the initial foliar application of B. Vertical bars represent the standard errors.

(a)

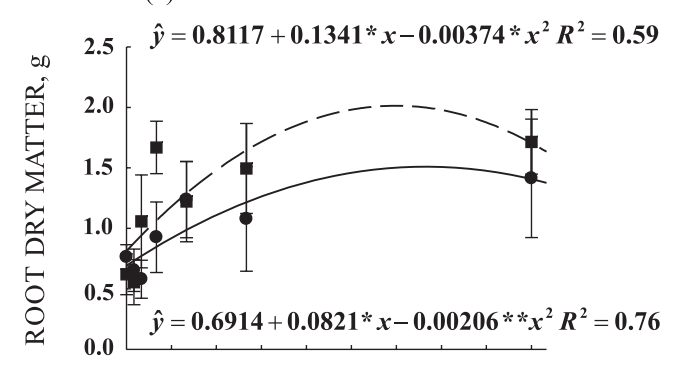

(c)

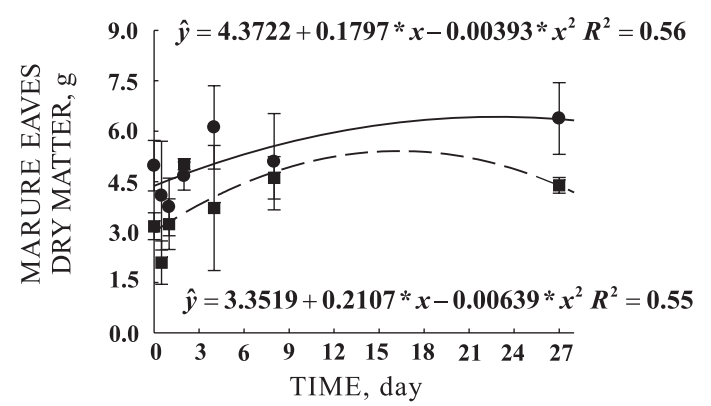

(b)

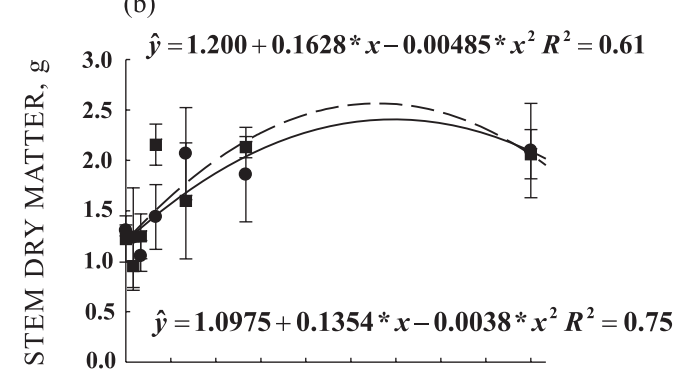

(d)

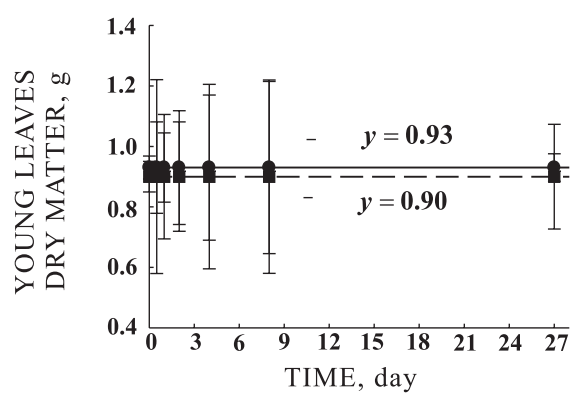

Figure 9. Dry matter of roots (a), stem (b); mature leaves (c) and basal leaves (d) of two eucalyptus clones (129 and 57) after a single application of boric acid to a mature leaf as affected by the time before removal of the B-treated (source) leaf. Plants of all treatments were harvested 27 days after the initial foliar application of $B$. Vertical bars represent the standard errors. 
detected in E. gunni/E. globulus and E. cypellocarpa/ E. globulus (Travert et al., 1997). The role of manitol in B mobility in eucalyptus is certainly an issue that deserves future investigation.
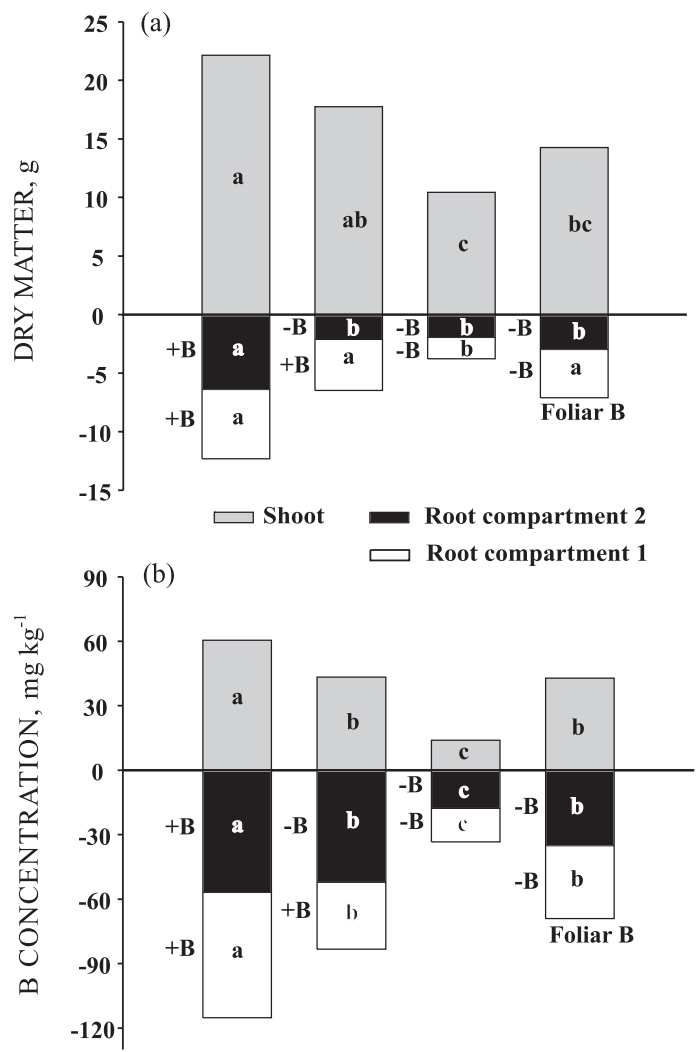

Figure 10. Dry matter (a) and B concentration (b) in the shoot and the two solution root compartments of clone 129 submitted to differential supply of $B$ to the root compartments with $(+B)$ and without $(-B)$ foliar B supply. Within each component (shoot, compartment 1 and compartment 2) Means followed by the same letter do not differ by Tukey's test (5 \%)

\section{CONCLUSIONS}

The collective results of this research show that eucalyptus clone 129 was less sensitive to B deficiency than clones 68 and 57, due to its ability to mobilize B from more mature to younger tissues. Boron is relatively mobile in eucalyptus, and B previously absorbed by roots may be retranslocated to some extent when plants face a condition of low B availability. Foliar-applied B is rapidly translocated to other plant components, which provides an alternative for rapid recovery of B-deficient plants. The use of a complexed B form is advantageous because it is more efficiently mobilized, but care must be taken to avoid phytotoxicity due to excess B accumulation. Finally, foliar application of B could be a strategy to cope with B-deficiency stress during the dry season when B-uptake from the soil is virtually stopped.

\section{ACKNOWLEDGEMENTS}

Dr. Ivo R. Silva is grateful for financial support from the CNPq-Conselho Nacional de Desenvolvimento Científico e Tecnológico. Financial support to Dr. Nairam F. Barros from FAPEMIG - Fundação de Apoio a Pesquisa do Estado de Minas Gerais is also acknowledged.

Finally, we are especially indebted to an anonymous reviewer and to the Associated Editor for their helpful questions, comments, and suggestions that significantly improved the manuscript quality.

\section{LITERATURE CITED}

ALTHOFF, P. \& OLIVEIRA, A.C. Eucalyptus dieback in "cerrado" areas in north-northwest of Minas Gerais. In: SHONAU, A.P.G., ed. Intensive forestry: The role of eucalypts. Pretoria, Southern African Institute Forest, 1990. p.598-609.

ANDRADE, S.C.; BARROS, N.F. \& NOVAIS, R.F. Exigência e distribuição de boro em mudas de Eucalyptus spp. Universidade Federal de Viçosa, MG, 1994. 36p. (Relatório final PIBIC/CNPq)

BARROS, N.F.; NOVAIS, R.F. \& NEVES, J.C.L. Fertilização e correção do solo para o plantio de eucalipto. In: BARROS, N.F. \& NOVAIS, R.F., eds. Relação solo-eucalipto. Viçosa, MG, Folha de Viçosa, 1990. p.127-186.

BELLALOUI, N. \& BROWN, P.H. Cultivar differences in boron uptake and distribution in celery (Apium graveolens), tomato (Lycopersicum esculentum) and wheat (Triticum aestivum). Plant Soil, 198:135-158, 1998.

BELlALOUI, N.; BROWN, P.H. \& DANDEKAR, A.M. Manipulation of in vivo sorbitol production alters boron uptake and transport in tobacco. Plant Physiol., 119:735$742,1999$.

BIELESKI, R.L. Sugar alcohols. In: LOEWUS, F. \& TANNER, W., eds. Encyclopedia of plant physiology. Berlin, SpringerVerlag, 1982. v.13. p.158-192.

BINGHAM, F.T. Boron. In: PAGE, A.L.; MILLER, R.H. \& KEENEY, D.R., eds. Methods of soil analysis. Chemical and microbiological properties, 2.ed. Madison, ASA-SSSA, 1982. Part 2. p.431-447. (Agronomy monograph, 9)

BLEVINS, D.G. \& LUKASZEWSKI, K.M. Boron in plant structure and function. Ann. Rev. Plant Physiol. Molec. Biol., 49:481-500, 1998. 
BROWN, P.H. \& SHELP, B.J. Boron mobility in plants. Plant Soil, 193:85-101, 1997.

BROWN, P.H. \& HU, H. Phloem mobility of boron is species dependent: Evidence for phloem mobility in sorbitol-rich species. Ann. Bot., 77:497-505, 1998.

BROWN, P.H.; BELLALOUI, N.; HU, H. \& DANDEKAR, A. Transgenically enhanced sorbitol synthesis facilitates phloem boron transport and increases tolerance of tabacco to boron deficiency. Plant Physiol., 119:17-20, 1999.

CLARK, R.B. Characterization of phosphatase of intact maize roots. J. Agric. Food Chem., 23:458-460, 1975.

DELL, B. \& HUANG, L. Physiological responses of plants to low boron. Plant Soil, 193:85-101, 1997.

EPSTEIN, E. Mineral nutrition of plants: Principles and perspectives. New York, John Willey \& Sons, 1972. 412p.

GOEDERT, W.J. Solos do cerrado: Tecnologias e estratégias de manejo. São Paulo, Nobel, 1985. 422p.

GONÇALVES, J.L.M.; BARROS, N.F.; NAMBIAR, E.K.S. \& NOVAIS, R.F. Soil and stand management for shortrotation plantations. In: NAMBIAR, S. \& BROWN, A.G., eds. Management of soil, nutrients and water in tropical plantation forests. Canberra, ACIAR, 1997. p.379-417.

GUPTA, U.C. Factors affecting boron uptake by plants. In: GUPTA, U.C., ed. Boron its role in crop production. Boca Raton, CRC Prees, 1993. p.87-104.

HU, H. \& BROWN, P.H. Localization of boron in cell walls of squash and tobacco and its association with pectin. Plant Physiol., 105:681-689, 1994.

HU, H.; BROWN, P.H. \& LABAVITCH, J.M. Species variability in boron requirements is correlated with cell wall pectin. J. Exper. Bot., 47:227-232, 1996.

HU, H.; PENN, S.G.; LEBRILLA, C.B. \& BROWN, P.H Isolation and characterization of soluble boron complexes in higher plants. The mechanism of phloem mobility of boron. Plant Physiol., 113:649-655, 1997.

HUANG, L.; BELL, R.W. \& DELL, B. Boron supply into wheat (Triticum aestivum L. cv. Wilgoyne) ears whilst still enclosed within leaf sheaths. J. Exper. Bot., 52:1731-1738, 2001.

KOBAYASHI, M.; MATOH, T. \& AZUMA, J. Two chains of rhamnogalacturonan II are cross-linked by borate-diol ester bonds in higher plants cell wall. Plant Physiol., 110:1017-1020, 1996.

LEHTO, T.; KALLIO, E. \& APHALO, P.J. Boron mobility in two coniferous species. Ann. Bot., 86:547-550, 2000.

LEHTO, T.; RÄISÄNEN, M.; LAVOLA, A.; JULKUNENTIITTO, R. \& APHALO, P.J. Boron mobility in deciduous forest trees in relation to their polyols. New Phytol., 163:333-339, 2004

LOOMIS, W.D. \& DURST, R.W. Chemistry and biology of boron. Biofactors, 3:229-239, 1992.
MARCAR, N.E.; GUO, J.; CRAWFORD, D.F. \& GUO, J.M. Response of Eucalyptus camaldulensis Dehnh., E. globulus Labill. ssp. globulus and E. grandis W. Hill to excess boron and sodium chloride. Plant Soil, 208:251$257,1999$.

MATOH, T.; ISHIGAKI, K.; MIZUTANI, M.; MATSUNAGA, T. \& TAKABE, K. Boron nutrition of cultured tobacco BY2 cells. I. Requirement for and intracellular localization of boron and selection of cells that tolerate low levels of boron. Plant Cell Physiol., 33:1135-1141, 1992.

NOIRAUD, N.; MAUROUSSET, L. \& LEMOINE, R. Transport of polyols in higher plants. Plant Physiol. Biochem., 39:717728,2001

NOVAIS, R.F.; BARROS, N.F. \& NEVES, J.C.L. Interpretação de análise química do solo para o crescimento de Eucalyptus spp. - níveis críticos de implantação e de manutenção. R. Árvore, 10:105-111, 1986.

OERTLI, J.J. \& RICHARDSON, W.F. The mechanism of boron immobility in plants. Physiol. Plant., 23:108-116, 1971.

PERICA, S.; BELLALOUI, N.; GREVE, C.; HU, H. \& BROWN, P.H. Boron transport and soluble carbohydrate concentrations in olive. J. Am. Soc. Hortic. Sci., 126:291296, 2001.

PICCHIONI, G.A.; WEINBAUM, S.A. \& BROWN, P.H. Retention and kinetics of uptake and export of foliageapplied, labeled boron by apple, pear, prune, and sweet cherry leaves. J. Am. Soc. Hortic. Sci., 120:28-35, 1995.

RAVEN, J.A. Short- and long distance transport of boric acid in plants. New Phytol., 84:231-249, 1980.

RERKASEM, B. \& JAMJOD, S. Genotypic variation in plant response to low boron and implications for plant breeding. Plant Soil, 193:169-180, 1997.

SGARBI, F.; SILVEIRA, R.L.V.A.; TAKAHASHI, E.N. \& CAMARGO, M.A.F. Crescimento e produção de biomassa de clone de Eucalyptus grandis x Eucalyptus urophylla em condições de deficiência de macronutrientes, B e $\mathrm{Zn}$. Sci. Flor., 56:69-83, 1999.

SHELP, B.J. Physiology and biochemistry of boron in plants. In: GUPTA, U.C., ed. Boron and its role in crop production. Boca Raton, CRC Press, 1993. p.53-85.

SHELP, B.J.; MARENTES, E.; KITHEKA, A.M. \& VIVEKANANDAN, P. Boron mobility in plants. Physiol. Plant., 94:356-361, 1995.

SHORROCKS, V.M. The occurrence and correction of boron deficiency. Plant Soil, 193:121-148, 1997.

STANGOULIS, J.C.R.; GREWAL, H.S.; BELL, R.W. \& GRAHAM, R.D. Boron efficiency in oilseed rape I. Genotypic variation demonstrated in field and pot grown Brassica napus L. and Brassica juncea L. Plant Soil, 225: 243-251, 2000.

STANGOULIS, J.C.R.; REID, R.J.; BROWN, P.H. \& GRAHAM, D. Kinetic analysis of boron transport in Chara. Planta, 213:142-146, 2001. 
SUBEDI, K.D.; GREGORY, P.J. \& GOODING, M.J. Boron accumulation and partitioning in wheat cultivars contrasting tolerance to boron deficiency. Plant Soil, 214:141-152, 1999.
TRAVERT, S.;VALERIO, L.; FOURASTÉ, I.; BOUDET, A.M. \& TEULIÈRES, C. Enrichment in specific soluble sugars of two eucalyptus cell-suspension cultures by various treatments enhances their frost tolerance via noncolligative mechanism. Plant Physiol., 114:1433-1442, 1997. 